\title{
STANISŁAW ŚNIESZKO
}

Z Instytutu Bakterjologji Rolniczej Uniwersytetu Stanowego w Madison, Wisconsin, U. S. A., (dyrektor prof. Dr. E. B. Fred) i z Instytutu Weterynarji $i$ Medycyny Doświadczalnej Uniwersytetu Jagiellońskiego w Krakowie, (dyrektor prof. Dr. Juljan Nowak).

(wptynęto 24.1.1934).

\section{DOŚWIADCZENIA}

\section{NAD BAKTERJAMI ROZKŁADAJĄCEMI BŁONNIK W WARUNKACH TLENOWYCH *).}

(Some Experiments on the Aerobic Cellulose Decomposing Bacteria).

Ilość węgla związanego w tkankach roślin znajdujących się na kuli ziemskiej odpowiada $1000-1100$ biljonom kg. bezwodnika węglowego ( $\mathrm{S} \mathrm{ch}$ roeder 1919). Ponieważ błonnik stanowi jeden z najważniejszych składników roślin wyższych, jasnem jest, że uwalnianie bezwodnika węglowego $\mathrm{z}$ obumarłych tkanek roślinnych jest jednym $\mathrm{z}$ najważniejszych procesów przemiany materji utrzymujących równowagę w przyrodzie. Ponieważ z nielicznemi wyjątkami zwierzęta nie wytwarzaja enzymów umożliwiających im trawienie błonnika, więc pozostają tylko drobnoustroje jako jedyne istoty, które posiadają zdolność rozkładania błonnika. Główną rolę odgrywają tu grzyby i bakterje.

*) Autor wykonal większą część doświadezeń opisanych w niniejszej pracy, jako stypendysta Fundacji Rockefellera. 
Pomimo jednak wielu badań przeprowadzonych na tem polu, wiadomości nasze co do biologji i stanowiska systematycznego tych drobnoustrojów sạ bardzo skape, a to z tego względu, że otrzymywanie ich w czystych hodowlach, co glównie odnosi się do bakteryj, do tej pory napotyka na wielkie trudności.

Bakterje te w zależności od ich wlaściwości biologicznych dzielone są zwykle na trzy zasadniče grupy t. j. rozkładające błonnik w warunkach 1) tlenowych, 2) beztlenowych i 3) termofilnych. Tą ostatnią grupe można jeszcze podzielić na dwie podgrupy, a mianowicie bakteryj Henowych i beztlenowych. Ponieważ tematem ponizej opisanych doświadczeń sạ bakterje należące do pierwszej grupy, więc w przeglądzie piśmiennictwa uwzględnione zostaną tylko odnośne prace.

Pierwsze bakterje należące do tej grupy zostaly opisane przez van Iterson a jun. (1901). Autor znajdowal je w mule, glebie i wodzie morskiej. Do wyosobnienia ich stosowal pożywki zawierające roztwór soli mineralnych oraz błomnik w formie bibuly do sạczenia. Celem otrzymania warunków tlenowych stosowal pożywke w b. cienkiej warstwie, lub też bibułe tak umieszczał w pożywce, że część jej wystawała ponad powierzchnie plynu. W takiej pożywce posianej materjalem z miejsc, w których w warunkach naturalnych odbywal się rozkład blonnika, uzyskiwal wzrost bakteryj i rozklad bibuły, który wysteppowal szczególnie silnie na granicy płynu i powietrza. Po kilku dniach hodowania w temperaturze od $25-35^{\circ} \mathrm{C}$, na bibule pojawiały się brunatne plamy, a ponizej bibuła zamieniała się na żóltą śluzową masę. Ponieważ metoda van Itersona nie nadawała sie do uzyskania czystej hodowli, znajdowały się tam różne formy, pomiędzy któremi jednak zawsze na pierwszem miejscu wystepowały dwa zasadnicze typy, t. j. cienka wysmukla laseczka i duzy ziarniak. Laseczka otrzymała niewłaściwa nazwee Bacillus ferrugineus, która to nazwa została nadana już dawniej przez R u ll ma n n a (1898) całkiem innej i błonnika nie rozkładającej bakterji. Iterson uważal ziarniaka za drobnoustrój, który ułatwia trawienie błonnika, lecz który sam nie bierze czynnego udziału w jego rozkładzie.

Nieco później M erker (1911) wyosobnił z liści Elodea dwa ziarniaki rozkładające błonnik, które nazwał Micrococcus cytophagus i Micrococcus melanocyclus, które rozkładały błon- 
nik w warunkach tlenowych. Hodowle te jednak nie były czyste.

Pierwsze, naprawdę czyste hodowle bakteryj rozkładających błonnik otrzymali uczeni amerykańscy Kellerman i II c Beth (1912). Badając produkujące metan hodowle „beztlenowych" bakteryj rozkładających błonnik wyosobnionych przez Omeliańskiego, otrzymali oni wtórnie z tej rzekomo czystej hodowli, trzy gatunki bakteryj rozkładających błonnik w warunkach tlenowych. Dwa z nich to jest $B$. rossica i $B$. flavigenes okazały się paleczkami bezzarodnikowemi, a trzeci B. am ylolylicus laseczką zarodnikującą. Wyosobnienia tych bakteryj dokonali autorowie na plytkach agarowych. Pożywka składała się z roztworu soli mineralnych, do których dodano delikatnie sproszkowanego błonnika i węglanu wapnia, dla zobojętnienia powstających kwasów. Na tych pożywkach bakterje te wytworzyły kolonje, a dookoła nich ukazały się przejrzyste obwódki, których powstanie autorowie tłómaczyli rozpuszczaniem błonnika. W dalszych doświadczeniach K ellerman, Me Beth, Scales i Smith (1913), wyosobnili z gleby szereg gramoujemnych laseczek, które rozkladały błonnik w warunkach wybitnie tlenowych, a na plytkach agarowych wytwarzały kolonje otoczone pierścieniem pożywki, w którym błonnik był rozpuszczony dzięki enzymom wydzielanym przez bakterje. Spostrzeżenia opisane przez autorów amerykańskich (Kellerman i M c B e th, 1912) spotkały się z ostrą krytyką O meli a ń s ki e go (19l3), lecz dzięki prostym a przekonywującym doświadczeniom Löhn is a i Lochhe a da (1913) zarzuty te zostały obalone.

Bakterje wyosobnione przez Kellermana i wspólpracowników rosły nie tylko na błonniku, ale dawały się hodować z powodzeniem na prawie wszystkich zwykłych podłożach bakterjologicznych, nie tracąc przez to nic ze swoich zdolności atakowania błonnika. W znanym podręczniku Bakterjologji systematycznej Bergey'a (1925) są te bakterje opisane pod nazwą rodzajową Cellulomonas.

Badania Kellermana i tow. byly powtórzone przez szereg autorów, lecz wyniki ich doświadczeń były w wielu wypadkach ujemne. Pring s h e im (1923) przebadal nawet niektóre z oryginalnych szczepów wyosobnionych przez Kellermana, lecz w żadnym wypadku nie udało mu się uzyskać rozkładu błonnika. Zapatrywanie Pringsheima, że hodowle wyosobnione 
przez autorów amerykańskich nie są właściwemi bakterjami rozkładającemi błonnik, lecz formami towarzyszącemi, podzielili tacy autorowie jak Hutchinson i Clay ton (1919), Gray i Chalmers (1924), Winogradzki (1929, 1932) i Bok or (1930). Poza Pringsheimem żaden z wymienionych autorów nie przebadał szczepów Kellermana, lecz swoje zapatrywania wygłosili jedynie na podstawie własnych ujemnych prób, wyosobnienia podobnych bakteryj. Autorowi niniejszej pracy (Ś ni e s z k o, 1929) udało się jednak oryginalnym szczepom wyosobnionym przez Kellermana i tow., hodowanym od roku 1912/13 na zwykłym agarze buljonowym, po szeregu niepowodzeń przywrócić utraconą, jak zdawało się już bezpowrotnie, zdolność rozkładania błonnika, przez hodowanie na wyjałowionej ziemi z dodatkiem błonnika. Doświadczenia te zostały w calości potwierdzone w pracy Skinnera (1929), która ukazała się w kilka miesięcy później. Również badania Waksmana i Heukelekiana (1924), Bradley a Rettgera (1927), jak i Dubosa (1928) wykazały, że niektóre przynajmniej ze szczepów Kellermana rozkładają błonnik. Ostatnio Winogradzki (1929), a szczególnie Kalnin s (1930), wyosobnili szereg nowych szczepów, z których wiele wykazuje znaczne podobieństwo cech do bakteryj wyosobnionych przez Kellermana i tow. Badania Winogradzki e go a szczególnie Ka ln in ŝ a wykazały ponad wszelką wątpliwość, że w przyrodzie znajduje się cały szereg gramoujemnych, bezzarodnikowych laseczek, które w warunkach tlenowych rozkładają błonnik. Również w warunkach na pozór beztlenowych bo w szlamie jeziora udało się Is sa c zence (1921) wykryć tlenowe bakterje rozkładające błonnik, a przypominające $\mathrm{z}$ opisu bakterje wyosobnione przez van Itersona*).

Drobnoustroje wyosobnione przez Issac\%enke wytwarzały jako pośredni produkt rozkładu błonnika substancje redukującą odczynnik Fehlinga, prawdopodobnie cellobiozę. Również Kalninşowi udało się wykazać podobne produkty przejściowe jeśli ograniczył dostęp tlenu przez zatopienie probówek parafiną. Ilość tej substancji była dość znaczną, bo dochodziła do $30 \%$ dodanego do pożywki błonnika. Autor podkreśla przy tem ważność przypuszczenia Prings heima

*) Thaysen i Bunker, 1927, str. 214. 
(1909, 1910, 1912, 1913), że bakterje rozkładające błonnik produkują węglowodany, które mogą służyć jako źródło energji dla wolno żyjących bakteryj wiążących azot atmosferyczny. Doświadczenia przeprowadzone nad hodowaniem bakteryj rozkładających błonnik razem z Azotobacter chroococcum (K alni n̂̀, 1930) wykazały, że ten ostatni może czerpać energję z produktów rozkładu błonnika, lecz bakterje rozkładające błonnik nie mogą korzystać z azotu przyswajanego przez Azotobactera.

Jedne z najdokładniejszych badań biochemicznych nad bakterjami rozkładającemi błonnik w warunkach tlenowych przeprowadził Simola (1931 a, 1931 b). Autor ten wyhodował dwa szczepy, względnie gatunki, laseczek zarodnikujących, a więc typu dotąd rzadko spotykanego przy tlenowym rozkładzie błonnika. Na szczególną uwage zasługują badania autora nad wytwarzaną przez te bakterje substancją redukującą płyn Fehlinga, która wbrew przypuszczeniom nie okazala się ani cellobiozą ani glukozą, lecz kompleksem oksyketokwasów, które przypominały te z kwasów próchnicowych, które nie posiadaja w 1 asności kolloidalnych. Bakterje te miały też zdolność produkowania z błonnika i źródel azotu zawartych w pożywce, substancji, która miała pewne własności białka. Powstanie takiej substancji białkowej, jako jednego z produktów bakteryjnego rozkładu błonnika, tak w glebie jak i w jelitach niektórych zwierząt, ma duże znaczenie dla przemiany materji w glebie i dla odżywiania zwierząt roślinożernych.

Bardzo ciekawym etapem w badaniach nad rozkładaniem błonnika w warunkach tlenowych i mezofilnych były odkrycia Hutchinsona i Claytona (1919). Autorowie ci wyhodowali z gleby pochodzącej z pól słynnej stacji doświadczalnej w Rothamsted, drobnoustrój, który żywo rozkładał błonnik i odznaczał się ciekawemi właściwościami morfologicznemi i biologicznemi. Drobnoustrój ten mógł być hodowany tylko na pożywkach zawierających błonnik i nieorganiczne związki azotowe, najlepiej azotany. Dodatek wysokodrobinowych organicznych związków azotu lub cukrów redukujących działał nań toksycznie. Pod względem morfologicznym występowal stale w dwu postaciach, a mianowicie nieco spiralnie zgiętej laseczki o zwężonych biegunach i wielkiego ziarniaka. Począt- 
kowo autorowie sądzili, że mają do czynienia z dwoma odrębnemi gatunkami żyjącemi w symbiozie. Ponieważ jednak nawet przy zastosowaniu najściślejszych w tym wypadku dostępnych metod, nie udało się autorom tych dwu form od siebie oddzielić, przeprowadzili odpowiednie obserwacje morfologiczno-rozwojowe, celem przekonania się czy te formy nie stanowią stadjów cyklu rozwojowego badanego drobnoustroju. Badania te wykazały, że drobnoustrój ten posiada szereg stadjów rozwojowych, przez które przechodzi od zgiętej i ostro na biegunach zakończonej laseczki do formy ziarniakowatej będącej formą przetrwalnikową. Poniewaz. forma laseczkowata w niektórych wypadkach przypominala nieco krętki i zdradzala ruchy pełzająco-oscylujące i w rozwoju swym posiadała formy ziarenkowate, autorowie zaliczyli ją do krętków i nazwali Spirochaeta cytophaga. Nazwa ta jakkolwiek została præyjęta przez szereg autorów późniejszych bez zastrzeżen, nie dała się długo utrzymać, ponieważ bliższe badania wykazały, że s. cytophaga nie ma nic wspólnego z krętkami. W młodych hodowlach na pożywce z błonnikiem występowały najpierw formy laseczkowate, które w miarę rozwoju ustępowały formom ziarenkowatym, zwanym przez autorów sporoidami. Sporoidy odznaczały się tylko nieznacznie zwiększoną odpornością na czynniki niszczące. Drobnoustrój ten w czystej hodowli i w warunkach ściśle tlenowych rozkładał energicznie błonnik. Do hodowania najlepiej nadawaly się pożywki stałe lub pólstałe. Błonnik był rozkładany \% wytwarzaniem niewielkich ilości kwasów organicznych, żółtego pigmentu, najprawdopodobniej identycznego z karotyną i znacznych ilości śluzu, który poddany hydrolizie nie rozpadal się na suistancje redukujące płyn Fehlinga. Jeszcze przed badaniami Hutchinsona i Ciaytona, niektórzy autorowie mieli do czynienia $z$ hodowlami rozkładającemi błonnik, a złożonemi z dwu form, t. j. laseczki i ziarniaka. Jak już wspomniano van I terson (1904) pierwszy, który opisał tlenowe bakterje rozkładające błonnik i z takiemi właśnie formami miał do czynienia, lecz uważal je stanowczo za dwa odrębne choć symbiotycznie żyjące drobnoustroje. Również G e s c h e r (1922) opisał drobnoustroje najprawdopodobniej identyczne ze $S$. cytophaga. Zapewne tylko nieznajomość pracy autorów angielskich była powodem, że autor ten twierdził, iz mial do czynienia z wspólżyjącemi ziarniakami i laseczkami rozkładającemi błonnik. 
Badania Geschera są też ciekawe i pod innym względem. Zauważył on, zresztą nie po raz pierwszy, wytwarzanie się enzymatycznych obwódek dookola kolonij bakteryj, rozkładających błonnik, w których to miejscach błonnik był rozpuszczony. Wedlug jego obserwacyj obwódki te nie byly wytworzone przez zaczyny wydzielane z bakteryj rosnących w kolonjach, leczprzez te bakterje kłóre przenikaly poży we i w niejposuwały sie w miarejak błonnik ulegal rozkladowi. Fakt ten mógłby posłużyć do wyjaśnienia obserwacyj poczynionych przez niektórych autorów, którzy zauważyli, że hodowle przez nich wyosobnione tracą szybko zdolność rozkładania błonnika, jeśli były hodowane na pożywkach stałych. W takich wypadkach by przeszczepiane bakterje towarzysące, które tworzyly typowe kolonje, a bakterje rozkladające błonnik i znajdujące się wewnątrzagaru przeszczepiane nie byly.

Najprawdopodobniej też bakterje rozkładające błonnik opisane przez Bojanowskiego (1925) i Bokora (1930) nie wiele się różniły od $S$. cytophaga. W i nog ra d z ki w swych obszernych badaniach $(1927,1928,1929)$ nad drobnoustrojami rozkładającemi błonnik opisał kilka gatunków, które według niego miały być identyczne, względnie pokrewne, ze S. cytophaga (Hutch. i Clayton). W in o g r a d zk i uważa, że forma ziarniakowata spotykana regularnie w hodowlach $C$. Hutchinsoni nie jest formą rozwojową, lecz drobnoustrojem wspólżyjącym, którego nie można oddzielić od formy laseczkowatej. Badania Winogradzkiego objęly cały szereg typów bakteryj rozkładających błonnik tlenowo i na podstawie swych doświadczeń podzielił je na kilka grup, które nazwał: 1) $C y$ tophaga, 2) Cellvibrio i 3) Cellfacicula.

Jako najważniejszy produkt rozkładu błonnika w warunkach tlenowych uważal Win og radzki t. zw. oksycellulozę, substancję której dokładniej nie określił, a którą identyfikował na podstawie własności barwienia. Nie był w stanie wyosobnić żadnych innych produktów rozkładu błonnika. Wak sman (1927) przypisywał $S$. cytophaga Hutchinsoni duże znaczenie przy rozkładzie błonnika w glebie. Oksycelluloza jest według Waksmana nie czem innem jak t. zw. "substancją 
komórkową“, która jest jedną z substancyj macierzystych próchnicy. Wyżej wspomniane doświadczenia Si moli (1931 b) rzucają pewne światło na powstanie i znaczenie tej „Zellsubstanz" w przyrodzie.

Ciekawy problem, czy istotnie $S$. cytophaga posiada cykl rozwojowy i czy stałe występowanie w jej hodowlach dwu form, t. j. ziarniaka i laseczki, należy uważać za cykl rozwojowy, czy też nierozerwalną symbiozę, zdaje się że został ostatecznie rozstrzygnięty dzięki pracom Krzemieniewskiej. W pierwszej pracy (1930) autorka wykazala, że formy ziarniakowata i laseczkowata sa tylko dwoma stadjami w cyklu rozwojowym tego samego drobnoustroju. Tak kształt jak i cykl rozwojowy $S$. cytophaga przemawia zdaniem autorki za tem, aby zaliczyć ten drobnoustrój do miksobakteryj, a szczególnie zaś do rodzaju Myxococcus. Dalej autorka wykazuje, że szczep Cytophaga Hutchinsoni wyosobniony przez W inogradzkiego nie jest identyczny ze Spirochaeta cytophaga autorów angielskich. Również udało się autorce (1933) śledzić pod mikroskopem kiełkowanie form laseczkowatych $\mathrm{z}$ okragłych form przetrwalnikowych i temsamem udowodnić, że formy te sa tylko stadjami cyklu rozwojowego tego samego drobnoustroju.

W pewnej sprzeczności z badaniami Krzemieniewskiej znajdują się doświadczenia opisane przez Ju dow ic zó wn ę (1932), która wyosobniła też Cytophage, lecz jak sama przyznaje nie w czystej hodowli. Autorka twierdzi, że udało się jej oddzielić formę laseczkowatá od ziarniakowatej i tą pierwszą hodować na żelu krzemionkowym bez żadnych dodatków. Ponieważ sama autorka twierdzi, że hodowle jej nie były zupełnie czyste, należałoby wyniki poddać krytyce i czekać na ich potwierdzenie na większym materjale doświadczalnym.

Ostatnio ogłoszone doświadczenia (Rippel i Flehming, 1933) polegające na wyosabnianiu przy pomocy mikromanipulatora pojedyńczych form ziarniakowatych z hodowli bakteryj rozkładających błonnik, a należących niewątpliwie do typu Cytophaga, potwierdzają doświadczenia Krzemienie ws ki ej wykazujące, że z form ziarniakowatych, przetrwalnikowych, kiełkują formy laseczkowate, a zatem że obie formy są tylko stadjami cyklu rozwojowego, a nie symbiozą dwu różnych gatunków. 


\section{CZĘŚĆ DOSWIADCZALNA.}

Materjał, z którego wyosobniono poniżej opisane hodowle przecinkowców rozkładających błonnik w warunkach tlenowych i mezofilnych, pochodzil z mulu z dna jeziora Mendota, położonego w pobliżu miasta Madison w Stanie Wisconsin w Stanach Zjednoczonych Ameryki Północnej.

W czasie mojego pobytu w Madison przeprowadzano właśnie badania nad przemianami gazowemi zachodzącemi w mule tego jeziora (Allgeier i tow., 1932). Badania te przemawiały za tem, że w mule jeziora muszą się odbywać procesy fermentacji błonnika, i dlatego też podjąłem się zadania, aby wyosobnić i opisać drobnoustroje czynne przy tych procesach.

Ponieważ badania chemiczno-fizyczne wykazywały, że w mule jeziora panuja warunki ściśle beztlenowe, dlatego też starałem się otrzymać hodowle, któreby fermentowały błonnik w takich samych warunkach. Prócz tego starałem się zbadać, czy w mule znajduja się té drobnoustroje rozkładające błonnik w warunkach tlenowych. Wstepne badania wykazaly, ze w mule tym znajdują się liczne bakterje rozkładające błonnik tlenowo i beztlenowo. Dalsze doświadczenia prowadzono w obu kierunkach, lecz w niniejszej pracy zostaną opisane tylko badania dotyczące bakteryj tlenowych.

W yos obnianie. Celem wyosobnienia bakteryj o których mowa, stosowano kilka metod. Zawsze jednak pierwszym krokiem było otrzymanie hodowli przygotowawczych na pożywkach, w których błonnik był stosowany o ile możności jako jedyne dostępne źródło energji. Tak do otrzymania hodowli przygotowawezych, czystych i do dalszych doświadczeń stosowano cały szereg pożywek, z których ważniejsze zostaną podane na wstępie, aby później uniknąć niepotrzebnego powtarzania.

\section{P O Ż Y W K I:}

I. Pożywa wg. Viljoena (1926).

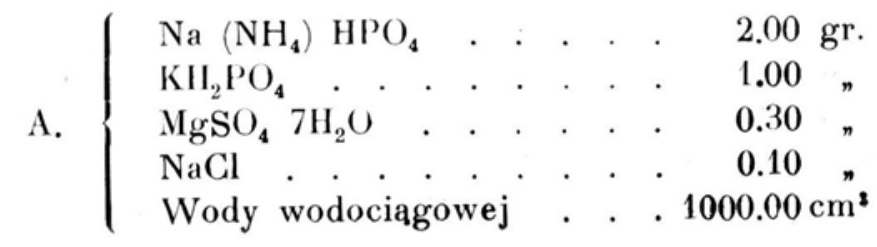




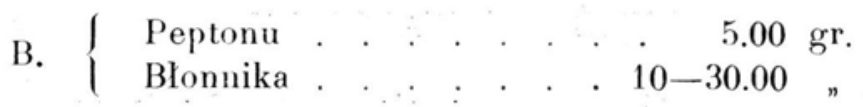

Dla przejızystości pożywka ta jest podzielona na dwie części A i B. Części A używano jako roztworu macierzystego dla przeważnej ilości pożywek stosowanych w opisanych tu doświadczeniach. Blonnik i pepton dodawano tylko w szczególnych wypadkach, co będzie każdorazowo zaznaczone w tekście.

II. Agar skrobiowy. (Kellerman i tow., 1913). Na $800 \mathrm{~cm}^{3}$ wrzącej wody dodano $10 \mathrm{gr}$. skrobji ziemniaczanej rozmąconej w malej ilości zimnej wody i gotując odparowano do $500 \mathrm{~cm}^{3}$. Do tego roztworu skrobji dodano $500 \mathrm{~cm}^{3}$ pożywki mineralnej Nr. I A i 10-20 gramów agaru. Časami dodawano nieco węglanu wapnia.

Wyciąg z ziemi. Wyciąg z ziemi przygotowywano w ten sposób, że do 2 litrów wody dodawano $1 \mathrm{~kg}$ ziemi zawierającej dużo próchnicy i $5 \mathrm{gr}$ węglanu wapnia sproszkowanego, poczem wyjaławiano pod ciśnieniem 2 atmosfer prez 1 godzinę. Następnie zostawiano w spokoju przez kilka dni, zlewano przejrzysty płyn $z$ wierzchu, który jeszcze filtrowano przez podwójne sączki papierowe. Kolor takiego płynu był cienno-brunatny.

III. Poży ka mineralnaz wyciągiem z ziemi.

Pożywki Nr. I A . . . . . $750-800 \mathrm{~cm}^{3}$
Wyciągu z ziemi . . . . $200-250$ ”

IV. Buljon zwykly:

Wyciągu mięsnego Liebiga (lemco) 3-4 gr.

Peptonu (Bacto). . . . . . 5-10

$\mathrm{NaCl} .+2 .+2.0 .5 \%$

$\mathrm{K}_{2} \mathrm{HPO}_{4}$. . . . . . . . . 0.5 "

Wody . . . . . . . $1000.00 \mathrm{~cm}^{3}$

Jeśli w miarę potrzeby używano pożywek o innym składzie niż wymienione, względnie używano ich modyfikacyj, w tekście zostanie nadmienione.

\section{WYOSOBNIANIE.}

Celem uzyskania hodowli wyjściowych przygotowano znaczną ilość probówek zawierających pożywki Nr. I A bez żadnych organicznych źródel azotu, lub też dodano azotı organicznego pod postacią $0.5 \%$ peptonu lub $0.2 \%$ asparagi- 
ny. Do pożywek tych dodano błonnika pod postacią pasków bibuły do sączenia, który umieszczono w probówkach w ten sposób, ze do $2 / 3$ były zanurzone w plynie, a $1 / 3$ wystawała ponad jego powierzchnię. Wszelkie późniejsze hodowle płynne w probówkach zawierających bibułę w paskach były w ten sposób przygotowane. Po wyjałowieniu zaszczepiono pożywki różnemi ilościami mułu z jeziora Mendota, który to muł poprzednio był trzymany przez pewien czas w naczyniach, z których tlen był zupełnie usunięty. Po zaszczepieniu tego materjału na wymienione pożywki, probówki umieszczono w cieplarce w temperaturze $+28-30^{\circ} \mathrm{C}$. W tej ciepłocie wykonano wszystkie doświadczenia opisane w niniejszej pracy.

Już po 24 godzinach pojawił się wzrost w pożywkach zawierających azot organiczny, a po 48 godzinach w probówkach z azotem mineralnym. W pożywkach zawierających azot organiczny, wzrost był bardzo silny i nieswoiste bakterje zwykle przerastały bakterje rozkładające błonnik. W pożywkach z mineralnemi źródłami azotu, a częściowo w pożywkach \% asparaginą, wzrost wystepowal przedewszystkiem na bibule na granicy płynu. Już po upływie $3-5$ dni bibuła była do tego stopnia na granicy płynu nadżarta, że za najlżejszem wstrząśnięciem probówką rozpadała się na poszczególne włókienka. W preparatach mikroskopowych wykonanych z pierwszych hodowli przygotowawczych, znajdowała się tak znaczna rozmaitość form, że trudno było rozstrzygnąć, które z nich odgrywały decydującą rolę w rozkladzie błonnika. Jak wspomniano, do wysiewu użyto różnych ilości materjału. Przed szczepieniem mul był rozcieńczony wodą wyjałowioną w stosunku $1: 10,1: 100,1: 1000$ i t. d. Wzrost baktery j, szczególniej w pożywkach zawierających azot organiczny, pojawiał się stale w rozcieńczeniu $1: 10^{6}$. W pożywkach $\mathrm{z}$ azotem mineralnym wzrost występowal jeszcze w rozcieńczeniach $1: 10^{4}$. Natomiast rozk kad błonnika w pożywkach $\mathrm{z}$ azotem organicznym wystepowal stale w rozcieńczeniu materjału 1 : 100, a czasem w $1: 1000$, a z azotem mineralnym stale w rozcieńczeniu $1: 10$, a często $1: 100$. Z tego wynikałoby, że albo w badanym materjale było niewiele drobnoustrojów tlenowych, rozkładających błonnik, albo że warunki doświadczalne bakterjom tym nie odpowiadały. Dalsze doświadczenia pozwoliły wnioskować, że ostatnie przypuszczenie było słuszniejsze. 
Zanim przystąpiono do prób otrzymania czystych hodowli, kilkakrotnie przeszczepiano hodowle przygotowawcze na te same pożywki.

Pierwsze próby otrzymania czystej hodowli wykonano metodą rozcieńczeń. $\mathrm{Z}$ otrzymanych hodowli przygotowawczych porobiono rozcieńczenia w wodzie wyjałowionej $\mathrm{w}$ stosunku 1: 10, 1 : $100 \mathrm{i}$ t. d. Po $1 \mathrm{~cm}^{3}$ tych rozcieńczeń zaszczepiono do takich samych pożywek płynnych, jakie były używane przy otrzymywaniu hodowli wstepnych, oraz do pożywek agarowych zawierających błonnik. Agar z błonnikiem był przygotowany w ten sposób, że do pożywki I A dodano tyle zawiesiny błonnika, przygotowanej metodą podaną przez Scales a (1915), że pożywka była mleczno-białą. Następnie dodano do pożywki 1.5 do $2 \%$ agaru przemytego i sproszkowanego. Do jednej serji pożywek dodano około $0.25 \%$ peptonu. Ponieważ obawiano się, że w grubej warstwie agaru zawierającego błonnik ze względu na jego małą przejrzystość trudno będzie dostrzec kolonje, czy też rozkład błonnika koło kolonij występujący, a cienka warstwa pożywki prędkoby wyschła, uniemożliwiając dłuższy okres hodowania, dlatego wylewano na płytki najpierw pożywke bez błonnika, a dopiero po jej zupełnem skrzepnięciu wylano drugą warstwę cienką, zawierającą błonnik i przed wylaniem zakażoną odpowiedniem rozcieńczeniem badanych bakteryj. Już w poprzednich doświadczeniach (Ś ni eszk o, 1929) metoda ta okazała się dobrą. Pożywki płynne i stałe po zaszczepieniu umieszczono w cieplarce o temperaturze $28^{\circ} \mathrm{C}$.

Najpierw wzrost ukazał się w hodowlach płynnych i na tych płytkach z agarem i błonnikiem, które zawierały dodatek $0.25 \%$ peptonu. W wyższych rozcieńczeniach materjału $\left(1: 10^{4}\right)$ rozkład błonnika wystąpił we wszystkich probówkach po 5 dniach. W plynnych pożywkach zawierających pepton, posianych wyższemi rozcieńczeniami hodowli przygotowawczych rozkład wystepował nieregularnie, ale wzrost był wszędzie obfity; badanie mikroskopowe wykazywało nadal obecność kilku różnych form bakteryj. Na pożywkach z asparaginą lub $z$ azotem mineralnym rozkład błonnika występował regularniej, aż do rozcieńczenia $1: 10^{6}$, a w rozcieńczeniach wyższych tylko sporadycznie. Ponieważ na pożywkach zawierających pepton lub asparaginę wzrost bakteryj pojawiał się $w$ rozcieńczeniach wyższych niż rozkład błonnika, nale- 
żało z tego wnosić, że w hodowlach przygotowawczych znajdowała się przewaga form niepożądanych i dlatego w dalszych doświadczeniach nie próbowano już otrzymywania czystych hodowli droga posiewania wysokich rozcieńczeń na pożywki plynne, uważając ten sposób za bezcelowy.

Na pożywkach agarowych zawierających pepton zawsze pojawiał się B. proteus, którego pełzający wzrost uniemożliwiał przeszczepianie pojedyńczych kolonij. Na płytkach niezawierających organicznych związków azotu, nie zauważono żadnego wzrostu, nawet po kilku tygodniach.

Poniewaz opisane próby uzyskania czystych hodowli nie powiodły się, próbowano metod innych. Tetrault (1930) wykazał, że termofilne bakterje rozkładające błonnik, mogą się rozwijać na agarze i blonnik rozkładać, jeśli koncentracja agaru w pożywce wynosi mniej niż $1 \%$. Przygotowano więc na roztworze macierzystym I. A pożywkę zawierającą błonnik strącony metodą Scalesa i tylko $0.8 \%$ agaru. Plytki przygotowano w ten sposób jak poprzednio $\mathrm{z}$ tem, że do dolnej warstwy niezawierającej błonnika dodano $1.5-2 \%$ agaru. Górną cienką warstwę zawierającą błonnik i $0.8 \%$ agaru, zaszczepiono rozcieńczeniani hodowli przygotowawczych. Po zupełnem skrzepnięciu wierzchniej warstwy agaru, plytki umieszczano w cieplarce. Ponieważ po kilku dniach nie zauważono żadnych śladów wzrostu ani rozkładu błonnika, przygotowano t. zw. agar skrobjowy zawierający normalną $(1.5-2 \%$ ) ilość agaru, który po wylaniu na plytki zaszczepiono przez rozcieranie na powierzchni materjału z hodowli przygotowawczych. Już po 24 godzinach ukazały się drobne kolonje, a po 2-3 dniach można ich było odróżnić kilka typów. Wszystkie typy rozkładały skrobję, co łatwo było stwierdzić, polewając płytki roztworem jodu. B. proteus na tej pożywce nie rósł, nie mając odpowiedniego źródła azotu. Po przeszczepieniu b. licznych kolonij do probówek zawierających pożywki z paskami bibuły, w kilku probówkach uzyskano nietylko wzrost, ale i rozkład błonnika na granicy płynu. Po przeszczepieniu powtórnem na agar skrobjowy, uzyskano wzrost kolonij jednego typu, które przeniesione na płynną pożywkę z błonnikiem bez wyjątku go rozkładały.

$\mathrm{Na}$ powyżej opisanych płytkach zawierających $0.8 \%$ agaru i błonnik, po 5 tygodniach hodowania ukazaly się pierwsze ślady rozkładania błonnika. Co prawda nie wytworzyły się 
typowe kolonje bakteryjne, lecz ukazały się małe, przejrzyste, okrągłe przestrzenie, w których pożywka straciła swoją matowość, zpowodu rozpuszczenia błonnika. W tychże miejscach agar był nieznacznie zapadnięty. Po przeszczepieniu materjału z tych pólek na płynne pożywki, bibuła została rozłożona w przeciągu kilku dni na granicy płynu.

Szczepy wyosobnione przy pomocy agaru skrobjowego i agaru z błonnikiem nie różniły się między sobą. Dalsze doświadczenia nad wyosabnianiem wykazały, że i na agarze z blonnikiem, też można uzyskać szybkie pojawienie się pól przejrzystych, świadczących o rozkładaniu błonnika, jeśli do pożywki dodano nieco wyciągu z ziemi. Fakt ten potwierdza poprzednie obserwacje (Śnieszko, 1929) które też wskazywaly na stymulujące działanie wyciągu z ziemi na bakterje rozkladające błonnik.

Przy pomocy powyżej opisanych metod wyosobniono z szeregu próbek szlamu z jeziora Mendota kilkanaście szczepów bakteryj rozkładających błonnik w warunkach tlenowych, kı́re międıy sobą prawie że się nie różniły. Charakterystyka ich została opracowana na podstawie „Man ual of Methods for Pure Culture Study of Bacteria” opracowanego prze s specjalną komisje towarzystwa amerykańskich bakterjologów (1923, 1926). Poniżej podane są najważniejsze cechy tych bakteryj:

Źród1o: Szlam \% dna jeziora Mendota w pobliżu miasta Madison w stanie Wisconsin w Stanach Zjednoczonych Ameryki Pólnocnej.

Kształt. Przecinkowato zgięte, małe laseczki średniej wielkości $2-3 \mu \times$ x $0.3-0.5 \mu$. posiadające jedną witkę biegunową, obdarzone żywym ruchem. Zarodników nie wylwarzają, barwią się metodą Grama ujemnie (ryc. $19 a$ i $b$ ).

\section{Würost na pożywkach.}

B u ljon z w y k ly (poż. Nr. IV). Wzrost b. skąpy w postaci jednolitego ledwie dostrzegalnego zmętnienia.

Agar skośny zwykły (poż. Nr. IV z dodatkiem $2 \%$ agaru). Dopiero po tygodniu pojawił się wzrost w postaci b. drobnych kolonij kolorı zóltawego. Wzrost występował zwykle tylko w pobliżu wody kondenzacyjnej znajdującej się na dnie probówki. 


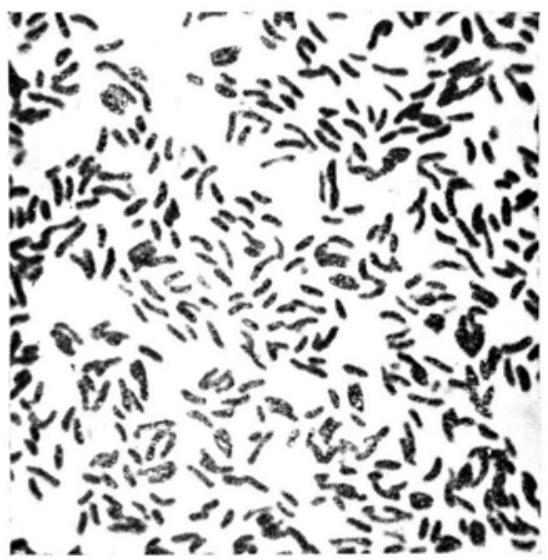

a

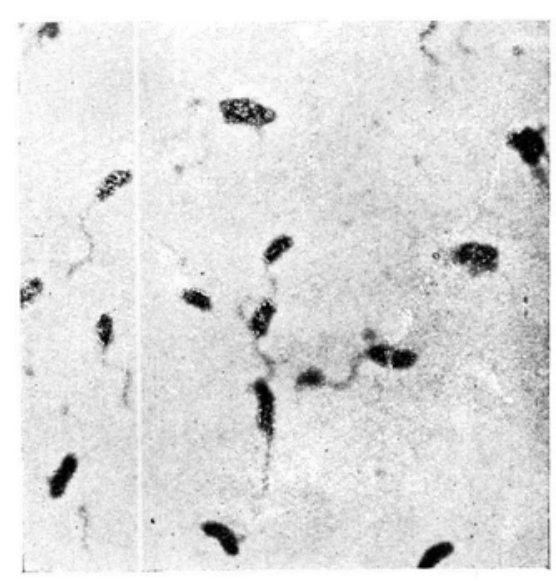

b

\section{Ryc. - Fig. 19}

a) Dwudniowa hodowla na agarze skrobjowym, barwiona fuksyną karbolową. b) Dwudniowa hodowla na płynnej pożywce z błonnikiem, rzęski barwione metodą Zettnowa. Powiększenie $2000 \times$.

a) 2 days old culture on starch-agar, stained with carbolfuchsine. b) 2 days old culture on liquid cellulose-medium stained by Zettnow method. Magnif. $2000 \times$.

$\dot{Z}$ elatyna (poż. Nr. IV z dodatkiem $15 \%$ żelatyny). Wzrostu nie zauważono ani na powierzchni ani w glębi pożywki.

Ziemniak. Makroskopowo wzrost nie dający się zauważyć. W preparatach mikroskopowych znajdują się laseczki o znacznie zmienionym kształcie.

Mleko z lakmusem. Po kilku dniach bardzo nieznaczne przesunięcia odczynu ku kwasocie. Żadnych innych zmian nie zauważono do 4-ch tygodni.

Pożywka Nr. III z błonnikiem. Błonnik był dodany pod postacią paska bibuły częściowo wystającego nad powierzchnią płynu. W pożywce takiej w 48 godzin od zaszczepienia ukazywało się jako pierwszy objaw wzrostu, nadżarcie błonnika bezpośrednio nad powierzchnią płynu, które można bylo poznać po tem, że gdy probówkę wstrząsano, z miejsca tego odrywały się liczne włókienka bibuły, które opadały na dno probówki. W preparatach mikroskopowych można było zauważyć, że włókienka były pokryte w zupełności zgiętemi laseczkami ułożonemi równolegle do długiej osi 
włókienka. W kilka dni od zaszczepienia bibuła była już tak przeżarta, że przy delikatnem wstrząsaniu probówką rozpadała się zupełnie, a pasek bibuly wyglądał jakgdyby przecięty nad powierzchnią płynu. Jeśli probówką nie wstrząsano w czasie wzrostu, to po kilku dniach pasek bibuły w miejscu znajdującem się kilka milimetrów nad powierzchnią płynu był pokryty delikatnym, jasno-żółtawym nalotem bakteryjnym. W hodowlach nie wstrząsanych pożywka była zawsze zupełnie przejrzysta, co świadezyło o tem, że bakterje rosły tylko na bibule.

Pożywka mineralna Nr. I A - z wyciągiem z ziemi i dodatkiem jednego z następujących węglow od an ó w: glukozy, fruktozy, galaktozy, ksylozy, arabinozy, maltozy, laktozy, sacharozy, mannitu i gliceryny. Wszystkie cukry z wyjątkiem fruktozy mogły służyć badanym bakterjom jako źródło węgla w zastępstwie błonnika. Alkohole, mannit i gliceryna nie podtrzymywaly wzrostu. W pożywkach z temi cukrami, które były bakterjom dostępne, wzrost pojawiał się przedewszystkiem jako kożuszek na powierzchni pożywki. Zmętnienie pożywki w głębi było naogół nieznaczne.

\section{Hodowle plytliowe.}

A gar zwy kły (skład jak wyżej). Wzrost nieregularny i bardzo skąpy w postaci drobnych $(0.2-0.5 \mathrm{~mm}$ średnicy) okrągłych, wypukłych kolonij koloru cytrynowo-żóltego.

Agar ze skrobją (pożywka Nr. II). Wzrost szybki i obfity. Kolonje 48 godzinne do $2 \mathrm{~mm}$ średnicy, okrągle, wypukłe, nieprzejrzyste, błyszczące, o jednolitym brzegu. Dookoła kolonij wytworzone były szerokie pierścienie diastatyczne, latwe do wykazania przez polanie jodem plytek, na których znajdowały się kolonje.

Plytki agarowe z błonnikiem. Agar przygotowany był przeważnie na pożywce Nr. I. A z $20 \%$ dodatkiem wyciagu $\mathrm{z}$ ziemi. Jak już wspomniano ważnem było, aby koncentracja agaru dodanego celem zestalenia pożywki nie wynosiła więcej niż $1 \%$. Zwykle dodawano $0.8 \%$ agaru. Plytki wylewane były zawsze z 2 warstw agaru t. j. dolnej grubszej bez błonnika i górnej cieńszej z błonnikiem. Powody dla których przygotowywano dwuwarstwowe plytki, zostaly podane powyżej. Blonnik dodawany w ilości okołe $1 \%$ do pożywki 
był przygotowany metodą S c a le s a (1915). Na płytkach przygotowanych w ten sposób bakterje nie wytwarzały typowych kolonij, a o wzroście można było przekonać się tylko z rozkładu zawartego w pożywce błonnika. Jeśli materjał został zaszczepiony przez dodanie znacznie rozcieńczonej zawiesiny bakteryj splukanych z błonnika, to począwszy od trzeciego dnia hodowania w ciepłocie $28^{\circ} \mathrm{C}$, zaczynały się pojawiać na phytce okrąłe miejsca, które stawały się przejrzyste dzięki temu, że błonnik w nich uległ rozpuszczeniu. Typowe kolonje tak charakterystyczne dla różnych gatunków bakteryj nie pojawiały się na tej pożywce. Bakterje te jednak miały zdolność wytwarzania zwykłych kolonij na innych pożywkach np. agarze ze skrobją i agarze zwykłym bez błonnika. Na pożywce z błonnikiem, która nie zawierała innego źródła energji prócz błonnika, nie wytwarzały się zupełnie typowe kolonje, a i błonnik nie był rozkładany, jeśli koncentracja agaru wynosiła więcej niż $1 \%$. Jeśli koncentracja agaru była właściwą $(0.8 \%)$ to przejrzyste, okrągłe przestrzenie pojawiające się w miejscu wzrostu bakteryj powiększały się szylıko tak, że po 7-10 dniach od chwili wysiania, pożywka na całej płytce stawała się przejrzystą spowodu zupełnego rozpuszczenia rawartego w niej błonnika. Doświadezenia wykazały, że w pożywce zawierającej tylko tyle agaru, ile było koniecznem do zestalenia jej, bakterje mogły się poruszać w miarę jak błonnik ulegał trawieniu i posuwały się dalej do miejsc, w których błonnik był jeszcze nierozłożony. Jeśli liczono ilość zdolnych do rozwoju bakteryj okazywalo się, że na obwodzie przejrystych przestrzeni t. z. tam, gdzie trawienie błonnika odbywało się najenergiczniej, było ich najwięcej. (Ryc. 20). Preparaty mikroskopowe, wykonane $\mathrm{z}$ agaru z blonnikiem pobranego z obwodowej części przejrzystych przestrzeni, wyka‘ywały wielką ilość bakteryj, które ściśle przylegały do włókienek błonnika i podobnie jak w pożywce płynnej, ułożone były równolegle do ich długiej osi. Też jeśli płytki, na których znajdowały się liczne przestrzenie, w których blonnik uległ strawieniu, polano jakimkolwiek odczynnikiem, ścinającym białko, to brzegi tych przestrzeni nabierały białawo-szarawego koloru, spowodowanego strąceniem się białka znajdującego się w komórkach bakteryjnych. jak też i syntetycznego (t. zw. substancji komórkowej, S i m o la, 1931 b), wytwarzanego przez bakterje podczas rozkładu błonnika. 


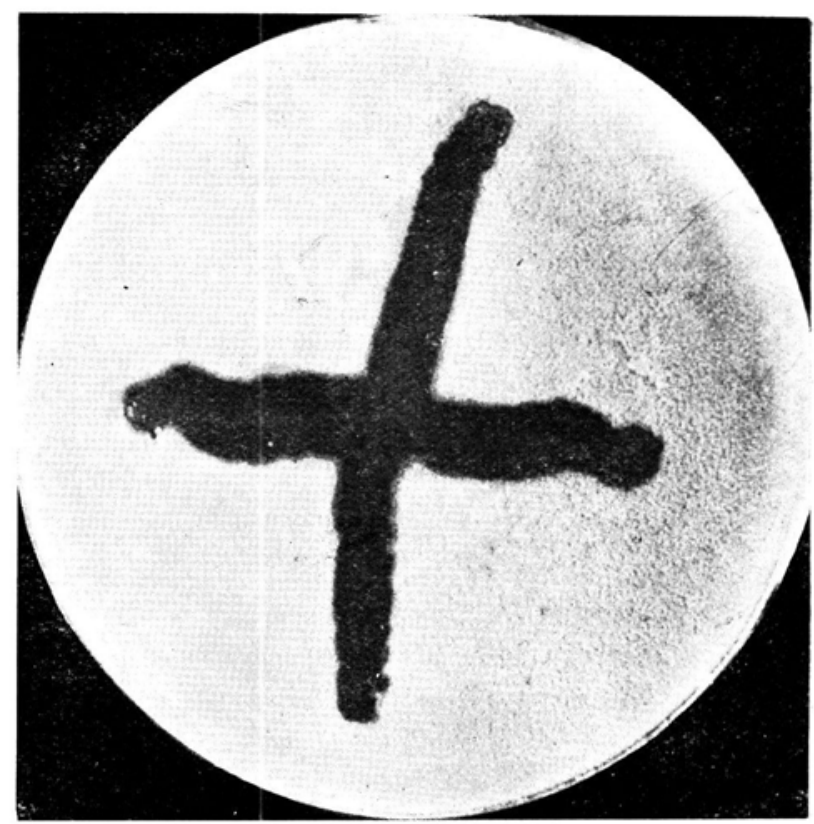

Ryc.-Fig. 20.

Czterodniowa hodowla na agarze z dodatkiem błonnika. Makroskopowo nie widać wzrostu bakteryj, lecz tylko o ich działalności swiadezącą przestrzeń w kształcie krzyża wywołaną przez rozpuszezenie błonnika zawartego $w$ agarze.

Four day old culture on cellulose-ag ir medium. Colonies are not formed but the cellulose is completely dissolved along the cross-like lines of inoculation.

Prawdopodobnie bakterje rozkladające blonnik w przyrodzie tylko w wyjątkowych wypadkach, t. zn. wtedy, jeśli ciała ich ulegają rozpadowi, wydzielają na zewnątrz zaczyny trawiące. Natomiast w warunkach normalnych trawienie błonnika odbywa się tylko wtedy, jeśli bakterje mają możność bezpośredniej styczności $\mathrm{z}$ włókienkami błonnika. Tem też możnaby wyjaśnić, że badane bakterje nie mogły błonnika rozkładać, jeśli koncentracja agaru była tak wielką, że uniemożliwiała im poruszanie się w pożywce i podążanie za błonnikiem w miarę, jak ulegał rozpuszczeniu. Podobne właściwości zauważono też u bakteryj rozkładających błonnik w warunkach termofilnych, gdzie tak długo nie można było uzyskać rozkładu błonnika na pożywce stałej, jak długo nie obni- 
żono stężenia agaru poniżej $1 \%$, (Tetra ult, 1930; Śnies zko, 1933; Śnieszko i Kimball, 1933).

\section{Wlasności biochemiczne.}

Z właśności biochemicznych uwzględnianych przy opisywaniu bakteryj nadmienić wypada, że badane szczepy nie wytwarzały indolu ani amoniaku i nie redukowały azotanów.

$\mathrm{Z}$ dodawanych do pożywek węglowodanów innych niż. błonnik, badane bakterje rozkladały $z$ wytwarzaniem śladu kwasów glukozę, galaktozę, ksylozę, arabinozę, maltozę, laktozę, sacharozę i skrobje, a nie rozkładały zupelnie fruktozy, mannitu i gliceryny. Jeśli do pożywki z wymienionemi węglowodanami dodano błonnika, to nie ulegał on rozkładowi, jeśli który z wymienionych węglowodanów był fermentowany. Blonnik dodany do pożywek zawierających dodatek fruktozy, mannitu lub gliceryny był rozkladany jak zwykle. Szczególy dotyczące fermentacji węglowodanów zostaną poniżej rozpatrzone obszerniej.

IIościowe doświadczenia nad rozkladaniem btonnika.

Pierwszą serję doświadczeń przeprowad zono w zwykłych kolbach Erlenmeyera pojemności 1 litra. Do kolb rozlano po $150 \mathrm{~cm}^{3}$ pożywki Nr. III (z wyciągiem z ziemi) i dodano błonnika pod postacią chemicznie czystej bibuly do sączenia, porozrywanej na strzępy i umieszczonej na perelkach szklanych, aby w duzej mierze wystawały ponad powierzchnię płynu, co było wskazanem dlatego, aby powiększyć powierzchnię zetknięcia z powietrzem. Do pożywki dodano niewielkich ilości osobno wyjałowionego węglanu wapnia i zaszczepiono przy pomocy kilku centymetrów sześciennych trzydniowej hodowli na pożywce z błonnikiem. Celem spłukania bakteryj z bibuły i równomiernego ich rozmieszczenia, próbówkę silnie wstrząsano przed pobraniem $\mathrm{z}$ niej materjału. Hodowano w temperaturze $28^{\circ} \mathrm{C}$ przez 24 dni. Już po kilku dniach bibułka w kolbach szczepionych rozpadała się łatwiej przy wstrząsaniu niz w kontroli. Pozatem nie zauważono żadnych innych zewnętrznych objawów rozkładu błonnika.

Po ukończeniu doświadczenia przesączono hodowlę przez tarowane sączki Goocha, przemyto gorącym rozcieńczonym kwasem chlorowodorowym, wodorotlenkiem sodowym i wodą destylowaną i doprowadzono do stałej wagi w suszarce w temperaturze $100^{\circ} \mathrm{C}$. Wyniki zebrane są w tablicy Nr. 1. 
T A B L I C A - T A B L E I.

Pierwsza serja doßswiadezeń nad ilością rozłożonego błonnika First series of experiments on the quantity of cellulose decomposed

\begin{tabular}{|c|c|c|c|c|c|c|}
\hline \multirow{3}{*}{$\begin{array}{l}\text { Nr. dośw. } \\
\text { Exp. No. }\end{array}$} & \multirow{3}{*}{ 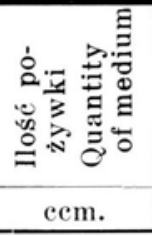 } & \multicolumn{2}{|c|}{$\begin{array}{c}\text { Do pożywki } \\
\text { dodano } \\
\text { Medium contained }\end{array}$} & \multirow{3}{*}{ 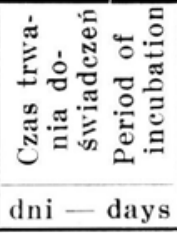 } & \multirow{2}{*}{\multicolumn{2}{|c|}{$\begin{array}{l}\text { Ilosś błonnika } \\
\text { rozłożonego } \\
\text { Cellulose } \\
\text { decomposed }\end{array}$}} \\
\hline & & \multirow{2}{*}{$\begin{array}{c}\begin{array}{c}\text { błonnika } \\
\text { cellulose }\end{array} \\
\text { gin. }\end{array}$} & \multirow{2}{*}{$\begin{array}{c}\mathrm{Ca} \mathrm{CO}_{3} \\
\mathrm{gm} . \\
\end{array}$} & & & \\
\hline & & & & & gm. & $\%$ \\
\hline 124 & 150 & 0,40 & 0,5 & 24 & 0,15 & 37,5 \\
\hline 125 & 150 & 0,68 & 0,8 & ” & 0,17 & 25,4 \\
\hline 126 & 150 & 1,36 & 1,5 & $"$ & 0,31 & 22,0 \\
\hline 127 & 150 & 0,40 & 0,5 & ” & $\begin{array}{l}\text { nie } \\
\text { not de }\end{array}$ & $\begin{array}{l}\text { zono } \\
\text { mined }\end{array}$ \\
\hline 128 & 150 & 0,68 & 0,8 & ” & 0,21 & 31,0 \\
\hline 129 & 150 & 1,36 & 1,5 & ” & 0,20 & 14,6 \\
\hline 130 & 150 & 0,40 & 0,5 & ” & 0,15 & 37,5 \\
\hline 131 & 150 & 0,68 & 0,8 & $"$ & 0,17 & 26,1 \\
\hline 132 & 150 & 1,36 & 1,5 & $n$ & 0,22 & 16,1 \\
\hline W 32 & 150 & 0,68 & 0,8 & n & 0,19 & 27,9 \\
\hline W 33 & 150 & 1,36 & 1,5 & $n$ & 0,11 & 8,0 \\
\hline
\end{tabular}

Druga serję doświadczeń wykonano w ten sam sposób z tą różnicą, że pożywkę i blonnik umieszczono w 3 litrowych kolbach fermentacyjnych o dnie bardzo wielkiem tak, że pożywka stykala się z powietrzem na znacznej powierzchıi. W każdej kolbie znajdowało się $250 \mathrm{~cm}^{3}$ pożywki i $1-1.5$ grama błonnika. Czas hodowania wynosił 21 dni. Ilość rozłożonego błonnika oznaczono w ten sam sposób jak poprzednio, z tą różnicą, że przesącz po przeplukaniu osadu na sączku gorącą wodą destylowaną, odstawiono do dalszych oznaczeń i dopiero potem osad pozostały na sączku przepłukiwano kwasem, ługiem i jeszcze raz wodą. Przesącz uzupełniano wodą destylowaną do stałej objętości i dzielono na kilka części, które służyły do ilościowego oznaczania produktów rozkładu błonnika w niem się znajdujących. W przesączu oznaczono ilość kwasóiv lotnych przez destylowanie próbki zada- 
nej kwasem siarkowym, przy pomocy pary wodnej i mianowano destylat wodorotlenkiem barowym. Kwasy nielotne wyciągano przy pomocy eteru siarkowego lub izopropylowego. Alkohol oznaczano w ten sposób, że próbkę przesączu alkalizowano, alkohol oddestylowywano i utleniano przy pomocy mieszaniny dwuchromianu potasowego i kwasu siarkowego. Powstałe przy tem kwasy oddestylowywano przy pomocy strumienia pary wodnej i mianowano wodorotlenkiem barowym. Kwasy lotne obliczano jako kwas octowy, a nielotne jako kwas mleczny. Wyniki podane są w tablicy Nr. II. Doświadczenia Nr. 185 i 186 wykonano w ten sposób, że pożywkę zaszczepiono mieszaniną bakteryj rozkładających błonnik i B.coli, celem przekonania się, czy taka hodowla mieszana będzie miała wpływ na ilość błonnika rozłożonego, oraz jakość i stosunek produktów rozkładu. Okazało się jednak, że obecność B.coli w hodowli nie wywarła żadnego zdecydowanego wplywu.

W doświadczeniach Nr. 353, 354 i 355 ilość błonnika dodanego do pożywki była znacznie większa niż poprzednio. Do kolb o pojemności trzech litrów o płaskiem dnie dodano $500 \mathrm{~cm}^{3}$ pożywki i $10 \mathrm{gr}$. blonnika. IV czasie trwania doświadezenia dwukrotnie dodano po $100 \mathrm{~cm}^{3}$ świeżej pożywki. Czas trwania doświadezenia wynosił trzy tygodnie. Po ukończeniu wykonano te same oznaczenia co poprzednio. Wyniki umieszczone są w tablicy $\mathrm{Nr}$. II (nr. 353-355).

\section{Wzrost $i$ zachowanie się bakteryj na pożywkach} z węglowodanami.

Jak juz wspomniano przy opisywaniu charakterystyki wyosobnionych szczepów, bakterje te nie były ograniczone do błonnika jako jedynego źródła węgla, lecz mogły rozkładać też i inne węglowodany. Celem przeprowadzenia doświadczeń przygotowano większą ilość pożywki Nr. III (poż. mineralna $\mathrm{z}$ wyciągiem $\mathrm{z}$ ziemi), rozdzielono w dokładnie odmierzonych ilościach do szeregu kolb i wyjałowiono. Osobno przygotowano w wodzie destylowanej $10 \%$ roztwory następujących węglowodanów, a mianowicie: fruktozy, galaktozy, ksylozy, arabinozy, maltozy, laktozy, sacharozy, mannitu i gliceryny. Roztwory te wyjałowiono, starając się o ile możności skrócić czas sterylizacji i nie przekroczyć ciopłoty $110^{\circ} \mathrm{C}$. Następnie do pożywki dodano jałowo tyle $10 \%$ roztworu da- 


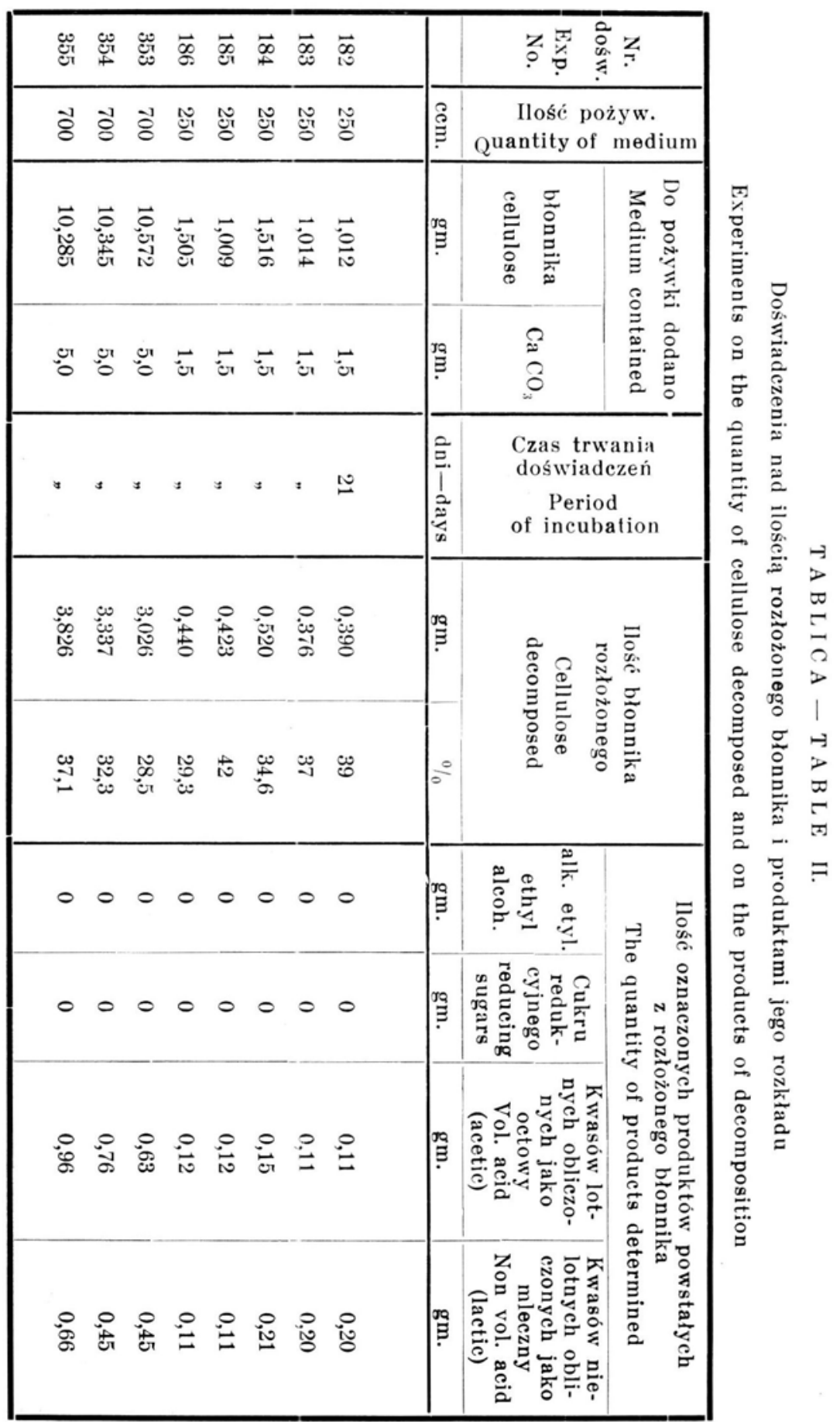


nego węglowodanu, aby w pożywce znajdował się dokładnie w ilości $1 / 2 \%$. Następnie pożywkę rozlano do wyjałowionych próbówek, poczem próbówki trzymano przez 4 dni w ciepłocie $28^{\circ} \mathrm{C}$, aby wykluczyć te $\mathrm{z}$ nich, w których pojawil się wzrost na skutek zanieczyszczenia powstalego podczas rozlewania pożywek. Do jednej serji pożywek dodano czerwieni bromo-krezolowej w stosunku 1:60.000, jako wskaźnika do wykazywania zmian $\mathrm{pH}$, mogących zachodzić w pożywce podczas doświadczenia. Do doświadczenia użyto czterech szczepów i każdym z nich zakażoa po 3 probówki z poszczegól. nemi weglowodanami. Do szczepienia użyto dwu kropli trzydniowej hodowli na pożywce $\mathrm{Nr}$. III z paskiem bibuły, którą silnie wstrząsano bezpośrednio przed pobraniem materjału do szczepienia. Po zaszczepieniu wszystkie probówki umieszczono w cieplarce o cieplocie $+28^{\circ} \mathrm{C}$. Czas trwania doświadczenia wynosil dziesięć dni. Już na drugi dzień po szczepicniu we wszystkich probówkach, z wyjątkiem tych, które zawierały fruktoze, mannit i glicerynę, pojawił się wzrost w postaci słabego zmętnienia. Po kilku dniach najsilniejszy wzrost ukazal się przy powierzchni plynu i w tem miejscu wystepowała też zmiana barwy wskaźnika świadcząca o słabem zakwaszeniu pożywki. W niektórych probówkach bakterje rosły jako kożuszek na powierzchni. Zakwaszenie pożywki nigdy nie było tak znaczne, aby w całej objętości pożywki wskaźnik zmienił barwę. Zmiana barwy utrzymywała się tylko przy powierzchni. Rozmaite szczepy w rozmaitych cukrach wytwarzały różne stopnie zakwaszenia. Na tablicy Nr. III. przedstawione są wyniki.

T A B L I C A - T A B L E III.

Zakwaszenie pożywek $\mathrm{z}$ węglowodanami

Acid formation in media containing carbohydrates

\begin{tabular}{|c|c|c|c|c|c|c|c|c|c|c|}
\hline 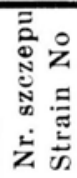 & 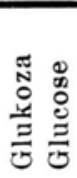 & 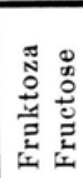 & 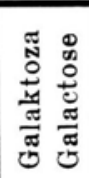 & 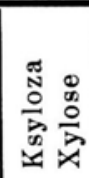 & 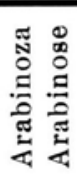 & 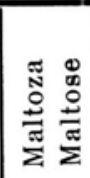 & 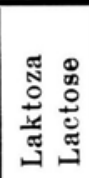 & 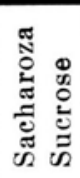 & 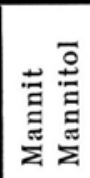 & 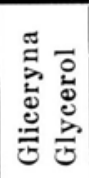 \\
\hline I & - & & & & $\ldots$ & + & ++ & + & & \\
\hline II & 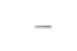 & 온? & & 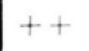 & +- & ++ & + & ++ & - 온로 & - \\
\hline III & - & $z$ & + & +- & $+t$ & +++ & + & + & - & - ئ \\
\hline IV & . & $1 \pi 0$ & ++ & +++ & ++ & ++ & +++ & + & -5 & - \\
\hline
\end{tabular}

Największa liczba krzyżyków wskazuje najsilniejsze zakwaszenie, pozioma kreska brak zakwaszenia. 
Równocześnie z tem doświadczeniem wykonano inne, polegające na tem, że te same pożywki z dodatkiem czerwieni bromo-krezolowej rozlano do rurek w kształcie litery „U”, których jedno ramię było zatopione. Poziom płynu w obu ramionach był jednakowy $\mathrm{z}$ tem, że w ramieniu zamkniętem pozostawiono słup powietrza wysoki około $30 \mathrm{~mm}$. Przed zaszczepieniem dokładnie zaznaczono na każdej rurce wysokość słupa powietrza. W kilka dni po zaszczepieniu do otwartego ramienia ,U” rurki, bakterje zawędrowały téz i do ramienia zamkniętego. W obu ramionach rurki tuż przy powierzchni płynu wzrost był najsilniejszy i w tychże miejscach wskaźnik wykazywał słabe zakwaszenie pożywki. W zamkniętych ramionach „L" rurek wysokość słupa powietrza zmniejszyła się o kilka milimetrów. Pomiary wykonywano w stałej temperaturze i uwzględniano zmiany ciśnienia atmosferycznego. W żadnej rurce wysokość slupa powietrza nie zwiększyła się. Wskazywało to na to, że bakterje musialy zużyć tlen znajdujący się w zamkniętej części rurki, nie wytwarzając żadnego gazu, któryby ten ubytek uzupełniał. Ma się rozumieć, że podczas wzrostu musiał być wytwarzany bezwodnik kwasu weglowego, lecz w tak niewielkiej ilości, że ulegał rozpuszczeniu w pożywce. W każdym razie to dość prymitywnemi środkami wykonane doświadczenie wskazywało, że proces oddechania tych bakteryj ma charakter wybitnie tlenowy. Procentowe zmniejszenie się ilości gazu wahało się w granicach $5-15 \%$. W pożywkach zawierajacych fruktozę, mannit i glicerynę zmian nie zauważono. W zamkniętych ramionach „U”, rurek, w których część powietrza zostala zużyta, zauważono przy powierzchni pożywki słabe zmiany koloru wskaźnika świadczące o zakwaszeniu.

Ponieważ w wyżej przedstawionych doświadczeniach okazało się, że ilości wytworzonych przez te bakterje kwasów są tak niewielkie, że wywolują ledwie dostrzegalne zmiany w $\mathrm{pH}$ podłoża, a $z$ drugiej strony wzrost bakteryj na niektórych cukrach był bardzo bujny, przypuszczano, że znaczna ilość cukrów dodanych do pożywki jest spalaną bezpośrednio na bezwodnik kwasu węglowego i wodę. Dlatego tez w jednej ze seryj pożywek z cukrami oznaczono po dziesięciu dniach hodowania ilość cukrów rozłożonych. Przy ilościowem oznaczaniu cukrów posługiwano się mikrometodą podaną przez Stilesa, Petersona i Freda (1926). Na tablicy Nr. IV. podane są procentowo ilości cukrów rozłożonych. 
T A B L I C A - T A B L E IV.

llość rozłożonych węglowodanów po 10-ciu dniach. Pożywka zawierała na początku doświadezenia $0,5 \%$ węglowodanów. Podane są procenty rozłożonych węglowodanów

The percentage of carbohydrates decomposed during 10 days of incubation. At the beginning the medium contained $0,5 \%$ carbohydrates

\begin{tabular}{|c|c|c|c|c|c|c|c|c|c|c|}
\hline 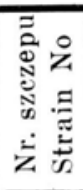 & 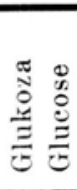 & 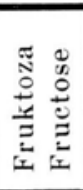 & 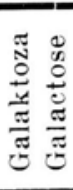 & 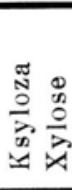 & 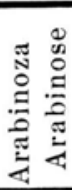 & 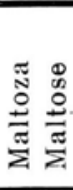 & 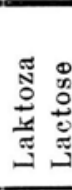 & 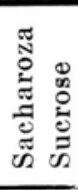 & 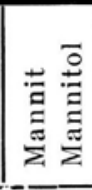 & 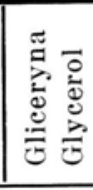 \\
\hline I & 29,6 & 6,5 & 29,6 & 24,0 & 18,5 & 18,5 & 11,4 & 10,5 & \multirow{4}{*}{\multicolumn{2}{|c|}{ 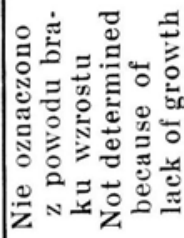 }} \\
\hline II & 34,5 & 0,2 & 29,4 & 30,0 & 31,7 & 22,5 & 24,0 & 12,4 & & \\
\hline III & 28,6 & 0,5 & 36,5 & 18,6 & 32,0 & 24,0 & 29,2 & 9,8 & & \\
\hline IV & 33,7 & 0,4 & 41,0 & 33,0 & 22.4 & 19,0 & 17,5 & 11,3 & & \\
\hline
\end{tabular}

Wplyw stęzenia jonow wodorowych w pozywce na rozklad blonnika.

Pożywkę Nr. III rozlano do szeregu kolb i kolometrycznie nastawiano pH przy pomocy lugu sodowego względnie kwasu chlorowodorowego tak długo, aż ustały wszelkie wahania plI. Po każdem nastawianiu pożywkę wyjałowiono. Po ostatecznem nastawieniu rozlano pożywkę do wyjałowionych probówek zawierających paski bibuły, które były tak długie, że częściowo wystawaly ponad powierzchnię plynu. Po dodatkowem jeszcze wyjałowieniu, w każdej probówce oznaczono reakcje i według tego oznaczenia rozdzielono probówki na serje o następującem pH: 4.4, 5.0, 5.5, 6.2, 6.5, 7.0, 7.4, 8.0, 8.5 i 9.0. Usunięto wszystkie probówki, gdzie pH nie zgadzało się z jednem z powyżej wymienionych. Odpowiednie serje probówek zaszczepiono czterema szczepami badanych bakteryj. Rozkład błonnika na granicy płynu wystąpił najszybciej, bo już po 48 godzinach w pożywkach o pH początkowem $7.0-8.0$, a więc to stężenie jonów wodorowych należy uważać za optymalne. W pożywkach o pH 9.0 rozkład bonnika wystąpił dopiero po ośmiu dniach, a więc gdy pożywka uległa już pewnemı zakwaszeniu z powodu adsorbcji bezwodnika węglowego z powietrza. W pożywkach o począt- 
kowem $\mathrm{pH}$ od $4.4-6.2$, rozkład błonnika nie wystąił nawet po dwu tygodniach. Po ukończeniu doświadezenia t. j. po czternastu dniach w każdej probówce zbadano pHI. Szczególny nacisk kładziono na dokładne zbadanie pH w pożywkach kontrolnych, które nie były szczepione i w znacznej liczbie pozostawały w takich samych warunkach. Wyniki podane sa w tablicy Nr. V. Krzyżyki oznaczają, że w pożywkach o danym $\mathrm{pH}$ nastąpił rozkład błonnika.

\section{A utoliza.}

Jak już zaznaczono, z pożywek nie zawierających błonnika, bakterje te rosły najlepiej na agarze zawierającym roztwór soli mineralnych i $1 \%$ skrobji. Na pożywce tej bakterje tworzyły kolonje okragłe, wypukłe o gładkich brzegach. Kolonje były nieprzejrzyste i posiadały zabarwienie koloru cytrynowego. Dookola kolonij skrobja była szybko hydrolizowaną, o czem latwo było się przekonać, polewając płytkę roztworem jodu. Na pożywce tej występowało rjawisko autolizy, które miało ludzące podobieństwo do bakterjofagji. Zwykle po $3-4$ dniach od wysiania $i$ to szczególnie jeśli na powierzchni agaru kolonje rozmieszczone były gęsto, w jednym lub rzadziej kilku miejscach równocześnie, kolonje z matowych stawały się przejrzyste i bezbarwne. Na większych kolonjach można było zauważyć nawet golem okiem, że najpierw jedna część kolonji ulegała temu losowi. Proces ten posuwał się tak szybko, że po kilkunastu minutach cała kolonja była zmieniona, a w kilka lub kilkanaście godzin później wszystkie kolonje na płytce były już autolizowane. Proces ten posuwal się koncentrycznie od miejsca, gdzie się najpierw ukazal i tem szybciej obejmowal cała płytkę, im gęściej były rozmieszczone kolonje. Lecz nawet gdy pomiędzy kolonjami był odstęp kilku milimetrów, to czynniki wywołujace go przedostawaly się przez pożywkę i powodowaly autolizę u najbliższych kolonij. Początkowo wydawało się, że jest to bakterjofagja, lecz bardzo licznie przeprowadzone doświadčenia polegające na tem, że przy pomocy filtratów z hodowli autolizowanych usiłowano wywołać podolne zjawisko, dały wynik ujemny. Proces ten występowat bowiem równie często wtedy, gdy zakażano hodowle przesączem, jak i wtedy gdy tego nie robiono. Doświadczenia utrudnial fakt, że w pożywach płynnych badane bakterje rosły skąpo tak, że pra- 


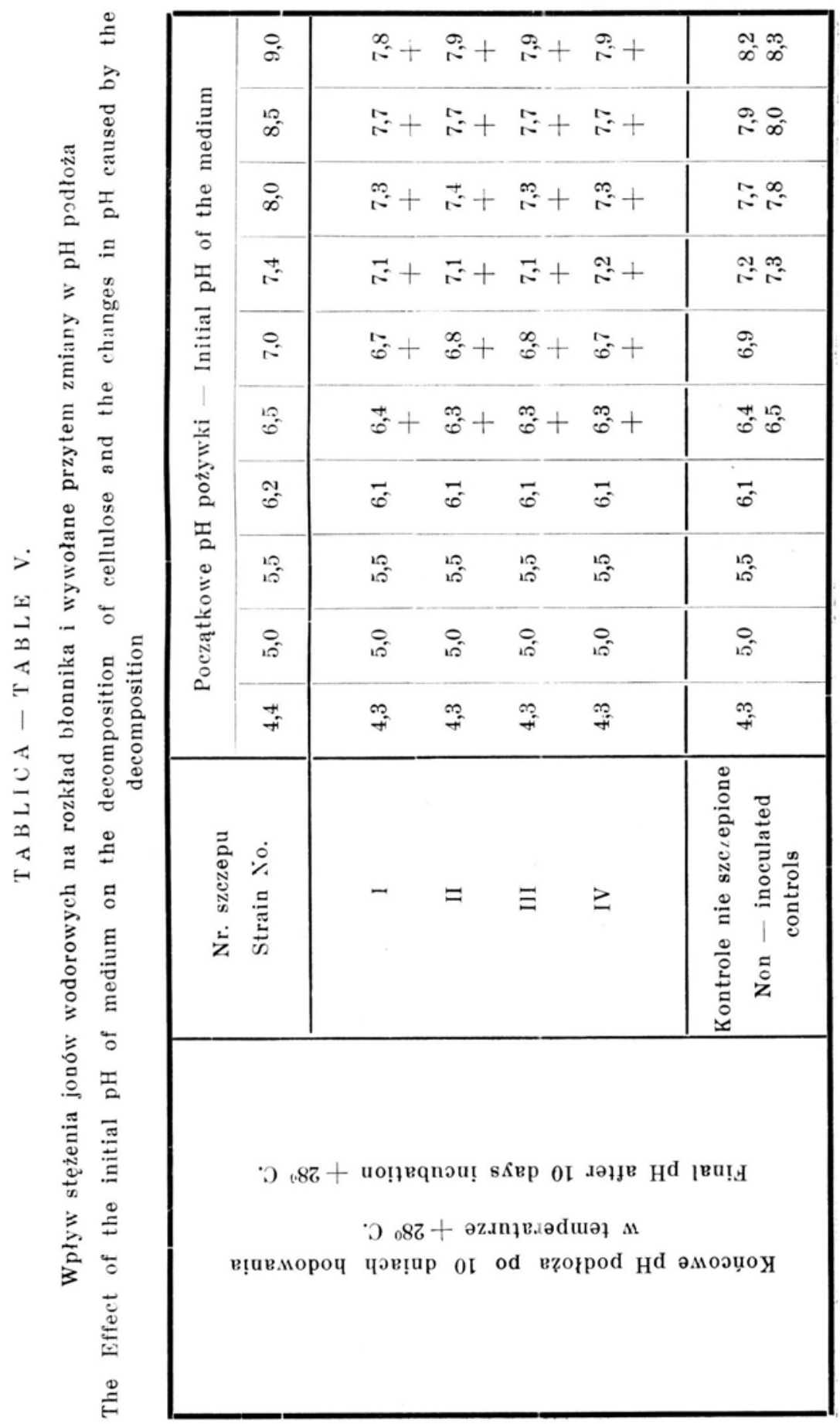


wie niemożliwem było zauważyć ewentualnego przejaśnienia się hodowli i dlatego doświadczenia z konieczności musiano ograniczyć do agaru skrobjowego. Bakterje, które uległy autolizie, traciły zdolność dalszego rozmnażania się. Jeśli wykonano posiewy z części kolonji, która nie uległa jeszcze autolizie otrzymywano wzrost normalny. Jeśli natomiast przeszczepiano z tej części, która już uległa rozpadowi, wzrost pojawiał się nie zawsze i tylko jeśli przeszczepiono dużą ilość materjału. W preparatach mikroskopowych z nieautolizowanych kolonij bakterje barwiły się latwo i regularnie, a z kolonij autolizowanych prawie że nie barwiły się zupełnie i nie posiadały określonego kształtu.

Gdy nadmieniłem przy okazji D-rowi Dubosowi z Instytutu Rockefellera (współautorowi prac nad enzymatycznem rozpuszczaniem otoczek węglowodanowych pneumokoków) o spontanicznej autolizie bakteryj w pracy tej opisanych, zażądal aby mu te bakterje przeslać. Niestety hodowle w międzyczasie zginęly, tak że doradziłem mu, aby spróbował powtórnej izolacji z mułu pochodzącego $\mathrm{z}$ dna jeziora Mendota. Jak w liście $\mathrm{z}$ dnia 1.VI. 1932 Dr. D u bo s doniósł, udało mu się ze szlamu wyosobnić bakterje podobne do opisanych powyżej, których autolizat rozpuszczal otoczkę pneumokoków typu II.

Wplyw czynnikow redukujących $i$ ulleniających na rozklad blonnika $i$ wzrost bakteryj.

Na zakończenie zostaną jeszcze przedstawione wynili doświadczeń przeprowadzonych nad wpływem redukujących względnie utleniających substancyj, na wzrost opisanych bakteryj i na rozkład błonnika. Przy wykonaniu tych doświadczeń wzorowano się na technice podanej przez Allyna i B a ldwin a (1930).

Próby przeprowadzono w pożywkach płynnych i stałych. Jako substancyj utleniających użyto nadmanganianu potasowego oraz nadtlenku wodoru, a jako redukujących kwasu thioglikowego i cysteiny. Substancje utleniające mogły być użyte bez poprzedniego zobojętnienia, zaś kwas thioglikowy i cysteina musiały być uprzednio zobojętnione, aby uniknąć zmian pH podłoża, które to zmiany mogłyby wpłynąć ujemnie na właściwą ocenę wyniku doświadczeń. 
Do pożywek płynnych (poż. Nr. III.) w probówkach z paskiem bibuły dodawano różne rozcieńczenia tak substancyj utleniających jak i redukujących i obserwowano ich wplyw na szybkość i sposób wystąpienia rozkładu błonnika. Dodatek substancyj utleniających nie wywierał w pożywkach płynnych większych zmian w rozkładzie błonnika. Dodatek zaś substancyj redukujących znacznie opóźnił rozkład błonnika, a linja najsilniejszego wzrostu bakteryj znajdująca się normalnie tuż nad powierzchnią płynu przesunęła się o 1 $1 \frac{1}{2}$ cm. wyżej:

Podobne doświadczenia wykonano też na pożywkach stałych. Przygotowano kilka porcyj $2 \%$ agaru z pożywką $\mathrm{Nr}$. III i do każdej porcji dodano jednej z wyżej wymienionych substancyj utleniających względnie redukujących w takiej ilości, że ostateczne rozcieńczenie w agarze wynosiło 1:1000. Kwas thioglikolowy i cysteina zostały uprzednio zobojętnione. Próbki tych pożywek zawierających te substancje wylano na płytki, które studzono sztucznie, aby przyśpieszyć krzepnięcie agaru. Gdy tylko agar się zestalił, powycinano z niego kwadraciki o boku około dwóch centymetrów i umieszczono po jednym z nich w jałowych płytkach Petriego. Do płytek tych następnie wlano tyle dwuprocentowego agaru przygotowanego $\mathrm{z}$ pożywką $\mathrm{Nr}$. III. że poziom jego był równy z powierzchnią kwadracików umieszczonych poprzednio na płytkach. Gdy agar się zestalił wysuszono wode kondenzacyjną i na płytki wylano pożywke rawierającą tylko $0.8 \%$ agaru i okolo $1 \%$ błonnika strąconego metodą Scalesa. Do pożywki tej ostudzonej do $45^{\circ} \mathrm{C}$ dodano uprzednio trzechdniowej hodowli badanych bakteryj, hodowanych na pożywce $\mathrm{Nr}$. III z paskiem bibuly. Następnie pożywkę tę wylano na płytki, w których znajdowała się już zestalona dolna warstwa agaru z zatopionemi w nim blokami zawierającemi dodatek substancyj redukujących względnie utleniających. Gdy i wierzchnia warstwa zaszczepionego agaru zawierającego błonnik też się zupełnie zestaliła, płytki umieszczono w cieplarce w temperaturze $+28^{\circ} \mathrm{C}$.

Już po trzech dniach pobytu w cieplarce na płytkach ukazały się liczne małe przejrzyste przestrzenie świadczące o zaczynającym się rozkładzie błonnika. Na płytkach zawierających bloki agarowe $\mathrm{z}$ dodatkiem substancyj utleniających zauważono stosunkowo nieznaczne przyśpieszenie rozkładu 
błonnika i pojawienie się w pobliżu bloków nieco liczniejszych i większych pól, w których błonnik był rozkładany. Natomiast substancje redukujące wywierały wpływ zdecowanie niekorzystny. W promieniu $1-2 \mathrm{~cm}$ od zatopionych bloków, rozkład błonnika i wzrost bakteryj byly zupełnie zahamowane i dopiero w nieco większej od nich odległości, można było zauważyć pojawienie się przejrzystych okrągłych pól, zwiększających się w miarę jak błonnik ulegal rozkładowi.

\section{S T R E S Z C Z E N I E.}

Podczas doświadczeń, które przeprowadzano nad procesami rozkładowemi odbywającemi się w mule jeziora Mendota pod miastem Madison w Stanie Wisconsin w Stanach Zjednoczonych Ameryki Północnej, udało się wyosobnić z powyżej wymienionego szlamu kilka szczepów przecinkowców, które w czystej hodowli dały się latwo hodować na zwykłych podłożach bakterjologicznych i rozkładały błonnik dość energicznie. Z całego szeregu pożywek nadawały się do wyosobnienia tylko pożywki agarowe, zawierające sole mineralne i skrobje lub zawiesine błonnika. Na innych pożywkach bakterje towarzyszące przerastały bakterje rozkladające błonnik, uniemożliwiając temsamem ich wyosobnienie.

Ze szczególnych własności posiadanych przez te bakterje wymienione zostaną tylko następujące:

1) Bakterje te rosły i rozkładały błonnik w warunkach ściśle tlenowych. Dodatek czynników utleniających do pożywki przyśpieszał rozkład błonnika.

2) $\mathrm{Na}$ pożywkach agarowych z dodatkiem zawiesiny blonnika rozkładały go one, jeśli koncentracja agaru wynosiła mniej niż $1 \%$, (optimum 0.7 do $0.8 \%$ agaru), ponieważ w tych warunkach pożywka utrzymywała się jeszcze w stanie stałym, a była dość rzadka, aby bakterje mogły się w niej poruszać. To jest ważnem $\mathrm{z}$ tego względu, że bakterje te na pożywce mineralnej zawierającej błonnik nie tworzyły typowych kolonij, lecz wędrowały w pożywee w miarę rozkładania błonnika, tak że jedynym makroskopowym dowodem ich istnienia było pojavianie się przejrzystych przestrzeni, w których błonnik ulegl zupełnemu rozkładowi.

3) Na pożywce zawierającej sole mineralne i skrobję, bakterje te tworzyły małe guziczkowe kolonje, koloru zólta- 
wego, dość szybko się rozwijające. Gdy na plytce znajdowały się gęsto rozmieszczone kolonje, to zwykle w jednym lub naraz kilku punktach występowała autoliza, która w przeciągu kilku lub kilkunastu godzin rozprzestrzeniała się po całej płytce. Bakterje rozpadały się, tracąc zdolność barwienia, kolonje z matowych stawały się przejrzyste, a przeszczepianie z nich na świeże pożywki zwykle nie dawało wzrostu. Dokładne badania wykazały, ze miało się tu do czynienia nie z bakterjofagją lecz autolizą. Na innych pożywkach stałych nie udało się zauważyć autolizy z tego powodu, że wzrost był bardzo skąpy.

4) Poza błonnikiem dodawano do pożywki następujących substancyj, z których rozkładane były: sacharoza, glukoza, ksyloza, galaktoza, maltoza, laktoza i arabinoza. Nie rozkładane były: fruktoza, mannit i gliceryna. Jeśli do pożywki mineralnej zawierającej błonnik dodano wyżej wymienionych substancyj, to jeśli substancje te byly rozkładane przez przecinkowce, to błonnik pozostawal nienaruszony. Jeśli zaś nie były rozkładane jak to miało miejsce z fruktozą, mannitem i gliceryną, to błonnik był w ich obecności rozkładany.

5) Badania ilościowe wykazały, że przecinkowce rozkładały w warunkach optymalnych okolo $40 \%$ błonnika, dodanego do pożywki. W produktach rozkładu znaleziono małe ilości kwasów lotnych t. j. octowego i masłowego i ślady kwasów nielotnych, najprawdopodobniej mlecznego.

\section{PIŚMIENNICTWO - BIBLIOGRAPHY.}

Allgeie r, R. J., Peterson, W. H., J uday, C. i Birge, E. A. (1932); Internat. Revue d. ges. Hydrobiol. u. Hydrographie, 26, s. $444-461$.

A 11 y n, W. P. i B a l d w i n, I. L. (1930): Journ. Bact. 20. s. 417-438.

Bergey, (1925): Manual of Determinative Bacteriology. First Edition. Baltimore. U. S. A.

B o j a n o w s k i, R. (1925): Zentr. Bakt. II. 64. s. 222-223.

B ok or, B. (1930): Archiv f. Mikrobiologie. 1. s. $1-34$.

B ra d ley, L. A. i Rettger, L. E. (1927): Journ. Bact. 13. s. $321-345$.

D u b o s, R. J. (1928): Journ. Bact. 15. s. 223-234.

G e s c h e r, N. (1922): Faserforschung. 2. s. 28-40.

Gray, P. H. i Chalmers, C. H. (1924): Annals of Applied Biology 11. s. $324-388$. 
H ute hinson, H. B. i Cla y to n, J. (1919): Journ. Agric. Sci.9. s. $143-172$.

I s s a c z e n k o, B. L. (1921): Bull. Rus. Hydraulical Inst. 1. s. 164173. Referaty w: Chem. Abstr. 18. s. 2731. (1924) i Abstr. B acteriology 8. s. 77. (1924).

I t e rs o n, C. jr. v a n. (1904): Zentr. Bakt. II. 11. s. $689-698$.

J u d o wi e z, Z. (1932): Med. Dośw. i Społ. 15. s. 64-83.

$\mathrm{K}$ a $\mathbf{l n}$ in s, A. (1930): Acta Universitatis Latviensis. I. 11. s. 221-312.

Kellerman, K. F. i M c. Beth, I. G. (1912): Zentr. Bakt. II. 34. s. $485-494$.

Kellerman, K. F., Me.Beth, I. G., Se ales, F. M. i S m i t h, N. R. (1913) Zentr. Bakt. II. 39. s. 502-522.

Krzemieniewska H. (1930): Acta Soc. Bot. Poloniae, 7. s. 507-519. „ (1933): Roczniki Nauk Roln.i Leśn. 30. s. 1-24.

Löhni s, F. i L o chhe a d. A. G. (1913): Zentr. Bakt. Il. 37. s. $490-492$.

Manual of Methods for Pure Culture Study of Bacteria, Edited by the Committee on Bacteriological Technik of the Society of American Bacteriologists. Geneva, N. Y. (1923, 1926).

M e r k e r, E. (1911): Zentr. Bakt. II. 31. s. 578-590.

O m e li a ń s k i, W. (1913): Zentr. Bakt. II. 36. s. 472-473.

P ri n g s h e i m, H. (1909): Zentr. Bakt. II. 23. s. 300.

” (1910): $\quad$ II. 26. s. 221.

” (1912): Zeitschr. f. physiol. Chem. 78. s. 266-291.

” (1913): Zentr. Bakt. II. 37. s. 111.

” (1923): Die Polysaccharide. 2. Aufl. Berlin.

Rippel, A. i Flehming, T. (1933): Archiv f. Mikrobiol. 4. s. $229-236$.

R u 11 m a n n, W. (1898): Zentr. Bakt. I. 24. s. 465.

S c a l e s, F. M. (1915): Zentr. Bakt. II. 44. s. 661-663.

S chroeder (1919): Cytowane według Simoli w Ann. Acad. Sc. Fenn. S. A. 34. No. 1. s. 1-91, 1931.

Si mol a, P. E. (1931 a): Ann. Acad. Se. Fenn. S. A. 34. No. 1. s. $1-91$.

Si mol a, P. E. (1931 b): tamże. No. 6. s. $1-115$.

S k i n n e r, C. F. (1929): Zentr. Bakt. II. 78. s. $508-512$.

Ś n i e s z k o, S. (1929): Zentr. Bakt. II. 78. s. $375-380$.

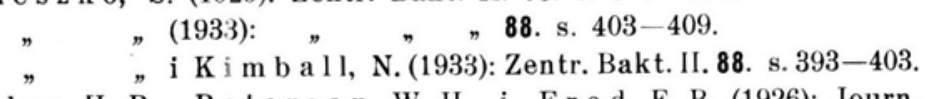

Stiles, H. R., Peterson, W. H. i Fred, E. B. (1926): Journ. Bact. 12. s. $427-439$.

T e tra u lt, P. A. (1930): Zentr. Bakt. II. 81. s. 28-45.

Th a y se n, A. C. i B u n ke r, H. J. (1927): The Microbiology of Cellulose, Hemicelluloses, Pectin and Gums. London.

Viljoen, J. W., Fred, E. B. i Peterson, W. H. (1926): Journ. Agricult. Sci. 16. s. $1-17$.

W a k s m a n, S. A. (1927): Principles of Soil Microbiology. First Edition. 
W a k s m a n, S. A. i Heukeleki a n, H. (1924): Referat w Zentr. Bakt. II. 69. s. 267.

W i n o g r a d z k i, S. (1927): Compt. Rend. Acad. Sci. 184. s. 493-497.

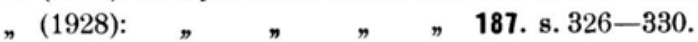

" (1929): Ann. Inst. Pasteur. 43. s. 549-633.

n (1932): Bull. Inst. Past. 30. 369-379.

\section{SUMMARY.}

In the course of studies on the processes of the decomposition of organic substances which is taking place in the slime at the bottom of Lake Mendota, located near the city of Madison, Wis. in the United States of North America, several strains of vibrio shaped cellulose decomposing bacteria were isolated from the above mentioned slime. Those bacteria could be cultivated on a number of the ordinary bacteriological media, but for the purpose of isolation only solid media containing agar, mineral salts solution, and, as sources of energy, starch or cellulose could be applied. On other media contaminating forms overgrew the cellulose bacteria.

Of the properties characteristic to these bacteria only the following need be mentioned:

1) The bacteria grew and decomposed the cellulose in strictly aerobic conditions. The addition of oxidizing substances stimulated the decomposition of cellulose, and the addition of reducing substances restrained their growth and the process of the decomposition of cellulose.

2) On the agar media with finely divided cellulose the cellulose was not decomposed when the medium contained more than $1-1,5$ per cent of agar. On such cellulose agar the bacteria never formed typical bacterial colonies, but grew on the cellulose fibres and moved in the medium following fibres which were not yet decomposed. Therefore the only macroscopic proof of their presence in the medium was the round and transparent spots which appeared on the plate as a result of the digestion of the cellulose in the medium. Therefore if the concentration of the agar in the medium was too high (optimum: $0,7-0,8$ per cent) the bacteria could not follow the cellulose fibres in the medium and the cellulose was not decomposed.

3) On the agar medium containing mineral salts solution and starch, the bacteria grew in form of typical button- 
like colonies of yellowish color which developed quite quickly. Quite frequently in one or more colonies autolysis appeared an spread over the whole plate in the course of 10 or more hours. Colonies which were opaque before autolysis became transparent and if transfers were made from such colonies, growth was uncertain. Bacteria taken from autolysed colonies did not stain well and had no definite form. In spite of the great similarity of this phenomenon to bacteriophage, thorough experimentation proved this to be autolysis. On other liquid or solid media it was impossible to observe autolysis because growth was very scant.

4) Besides cellulose the following sugars were decomposed: sucrose, glucose, galactose, maltose, xylose, lactose and arabinose. Fructose, mannitol and glycerol were not decomposed. If any of the above mentioned substances subject to decomposition by these bacteria were added to the medium containing cellulose, the cellulose was not decomposed. If however fructose, mannitol and glycerol were added to the above medium, the cellulose was decomposed as usual.

5) In optimal conditions about 40 per cent of the cellulose present in the medium was found to be decomposed. Among, the products of decomposition small quantities of volatile acids were found, i. e. acetic and butyric, as well as traces of some nonvolatile acid, most probably lactic. 